\title{
Language and lifeworld Schutz and Habermas on idealization
}

\author{
Linguagem e mundo-da-vida
}

Schutz e Habermas sobre idealização

(1) Jan Strassheim*

\begin{abstract}
Jürgen Habermas seminally criticized Alfred Schutz. This paper traces the disagreement back to a different role of idealization. Schutz's social theory is based on "types" as idealizations with an inherent dynamics, while Habermas's social theory is based on ideally stable "rules". First, a rule model of linguistic communication is assessed against analyses from linguistics and the philosophy and sociology of language. A rule model, it is found, fails to meet its theoretical goal of explaining linguistic communication. Hypothetical rules of language would not explain our intuitive understanding of the minimal propositional contents expressed by utterances. The rules would be both insufficient and unreliable in every single instance of language use. Against this background, the relation between language and "lifeworld" is then re-evaluated. A lifeworld cannot build on a rule model of language as its foundation. Nor can it supplement such a model in order to save it. Unlike a rule model, Schutz's claim that language and lifeworld are interconnected and structured by "types" that can accommodate the flexibility and precision of linguistic communication. While further research is needed, this conclusion indicates that phenomenology has been unduly neglected in social philosophy and should receive as much attention as it has in sociology.
\end{abstract}

Keywords: Theories of communication. Typification. Linguistic rules. Phenomenology of the lfe-world. John Searle.

Resumo: Jürgen Habermas criticou Alfred Schutz de maneira seminal. Este artigo traça tal divergência até a diferença na conceitualização de idealização. A teoria social de Schutz é baseada em "tipos" enquanto idealizações com uma dinâmica inerente, enquanto a teoria social de Habermas é baseada em "regras" idealmente estáveis. Primeiramente, um modelo de regra de comunicação linguística é avaliado de acordo com análises da linguística, da filosofia e da sociologia da linguagem. É constatado que um modelo falha em alcançar seu objetivo teórico de explicar a comunicação linguística. Regras de linguagem hipotéticas, portanto, não explicariam nossa compreensão intuitiva de conteúdos proposicionais mínimos expressos em enunciados.

\footnotetext{
* PhD. in Philosophy at the Free University of Berlin (Germany). Guest researcher and lecturer at the Faculty of Letters, Keio University, Tokyo, Japan <jan.strassheim@fu-berlin.de>.
} 
As regras seriam tanto insuficientes quanto incertas em todas as instâncias do uso da linguagem. Neste contexto, a relação entre linguagem e "mundo-da-vida" é reavaliada. Um mundo-da-vida não pode ser constituído sobre um modelo de linguagem, nem mesmo suplementar tal modelo a fim de preservá-lo. Diferentemente de um modelo, Schutz reivindica que linguagem e mundo-da-vida estão interconectados e estruturados em "tipos" que podem acomodar a flexibilidade e a precisão da comunicação linguística. Embora seja necessário o aprofundamento da pesquisa, as conclusões apontam que a fenomenologia tem sido indevidamente negligenciada pela filosofia social, e deveria receber maior atenção, assim como tem recebido na sociologia.

Palavras-chave: Teorias da comunicação. Tipificação. Regras linguísticas. Fenomenologia do mundo-da-vida. John Searle.

\section{Introduction}

Phenomenology has had a lasting influence in sociology. One important road for its influence was Alfred Schutz's theory of the social world inspired by phenomenology. ${ }^{1}$ Given that phenomenology, originally a philosophical approach, left a footprint in the discipline dedicated to the study of the social, we should expect a comparable influence within philosophy itself where it deals with social theory. But the story is quite different here. Leading social philosophers John Searle and Jürgen Habermas dismissed phenomenology, and Schutz's work in particular, as either irrelevant or obsolete. These prominent dismissals had a lasting effect in the field. Despite recent work arguing the significance of phenomenology for dominant philosophical discourses on social phenomena (Zahavi and Satne, 2016), it seems fair to say that phenomenology is still marginal at best in philosophical social theory. This raises the question, relevant to any sociological approach influenced by Schutz or other phenomenologists, whether a phenomenological take on the social world is outdated on its philosophical home ground.

Searle criticized Schutz for ignoring the fundamental role of language in the construction of social reality. Schutz, he says, took language "for granted" (Searle, 2006, p. 14). But in view of Schutz's extensive work on language and its role in the construction of social reality, Searle's remark leaves unclear what it is, in his mind, that Schutz neglected. Unfortunately, Searle never elaborated on his criticism. ${ }^{2}$ The work of Jürgen Habermas, whose view of language

\footnotetext{
${ }^{1}$ Approaches influenced by Schutz include Berger and Luckmann (1966); Garfinkel (1967); Goffman (1974); Schutz and Luckmann (1989).

${ }^{2}$ Searle qualified his criticism of Schutz in his public lecture "Language, collective intentionality, and social ontology" at the conference Collective Intentionality VII in Basel, Switzerland, on 24 August 2010 by adding, "though perhaps I should not say Schutz, because I haven’t read him".
} 
builds heavily on Searle's, gives us a better understanding of the objections involved. Habermas too criticized Schutz early on for allegedly ignoring the fundamental role of language (Habermas, 1988, p. 112). But he goes into more detail as to how Schutz's approach differs from his own.

In the present paper, the disagreement between Habermas and Schutz will be reconstructed in terms of the different roles they accord to idealization both at the level of the social world and in a theory of it. This difference is bound up with that between Schutz's concept of "type" and Habermas's concept of "rule". Two distinct accounts of how our flexible and precise linguistic communication is possible are built on these two concepts. These accounts yield two different theories of how language and the lifeworld beyond language are related to each other. I will contrast the two accounts and then assess a rule model of linguistic communication against evidence from linguistics and the philosophy and sociology of language. From this I will draw some conclusions about the theoretical viability of the two positions as accounts of how language and lifeworld are related.

Eventually, Schutz's earlier position will be found not only to stand against the objections, but to be actually more advanced on a theoretical level than the position of Habermas. Insofar as the disagreement between the two concerns questions fundamental to any theory of the social world, be it philosophical or sociological, this conclusion indicates that phenomenology has been unduly neglected in social philosophy and that it offers the resources for further productive developments in social theory.

\section{The puzzle of communication: idealization in Schutz and Habermas}

Communication is a curious phenomenon if we recall that, as individuals, we have different outlooks, moods and perspectives, beliefs and memories, plans, priorities and desires. How is it possible that two or more individuals pay attention to the same event in their environment, correctly attribute complex thoughts or emotions to one another, act in unison, or even fight each other with a shared understanding of what they are fighting about? How can we coordinate our individual standpoints in concrete situations?

An obvious answer is that we talk or write in a shared language. Like other means of communication, language works through material signals which can be produced and perceived by different individuals and which can thus connect these individuals. But language stands out among other means of communication thanks to its high precision and flexibility. It can be tailored to an indefinite range of ever new purposes and situations. It makes sense then to 
see language as "the paramount vehicle of communication" (Schutz, 1964a, p. 160), a point on which Schutz and Habermas could certainly agree. But then the question is: how can different individuals use words to understand each other in ever new situations? On what basis is our precise and flexible linguistic communication possible?

In order to approach this question, we should start by trying to say what a language is. A commonsensical reply would be that a language provides a system of more or less fixed patterns: words and their usual meanings, correct grammar, standard expressions etc. Native speakers simply use these patterns as a matter of daily routine, but they can be made explicit in dictionaries or in explanations we give to non-native speakers. To share a language is to share such a system of patterns, and to use them in a way which is similar across different individuals in the group. But just how 'fixed' are the patterns? This question leads to a theoretical crossroads which has to do with idealization.

Schutz describes linguistic patterns in terms of "typification". Types shape and motivate most of our experience and action. Typical traits we can recognize and reproduce enable us to live in a familiar world and to share this world with others who operate on similar types. Our "lifeworld", as Schutz calls it with reference to Husserl, operates on typical patterns. "The typifying medium par excellence" (Schutz, 1962a, p. 14) is language. Through its grammar and vocabulary, a language draws distinctions and singles out certain objects, events and relations. According to Schutz, these linguistic patterns correlate with what the users of the language - especially its native speakers - find typically relevant.

The important point is that types, as Schutz uses the term, have a peculiar dynamics. Most of the time, we take our typical expectations and routines "for granted" without even questioning them. But we do so only "until further notice". A type can be "questioned" at any time if necessary, and it can be modified or given up as the case requires. Schutz's insistence on the dynamic character of a type reflects his particular phenomenological stance. Husserl's "eidetic" method was to look for ideally invariant structures of consciousness. Schutz (1966b) contended that this method cannot be applied to patterns on a social scale. Schutzian "types" may change over time, and they are not uniformly valid for different individuals within a group.

Types, as Schutz points out, are rooted in three basic "idealizations" used by the actors in a social world. (1) When I stick to a typical expectation, I assume that things will remain just as they used to be (an idealization Husserl calls "and so forth"). (2) When I act according to a typical routine, I assume that my action will proceed just the way it used to do (an idealization Husserl 
calls "I can do it again"). (3) In my communication with others, I operate on a meta-idealization, (the "general thesis of reciprocal perspectives"): I assume that we use the exact same types and that we will continue to do so. But none of these idealizations is compulsive or beyond doubt. All three basic assumptions follow the dynamics of the typical: they are "taken for granted", but only "until further notice". ${ }^{3}$ Schutz's theory of the social world makes a point of reflecting this inherent dynamics of its object rather than imputing ideally invariant structures to it.

Habermas disagrees. Referring to Schutz and Luckmann's characterization of the "lifeworld" as "taken for granted until further notice", he strikes out the qualification "until further notice", claiming that "the commonality of the lifeworld has to be understood in a radical sense" (Habermas, 1987). The basis for his claim is a theory of communication which has at its heart a rule model of language. According to the model, grammatical and semantic patterns are not variable types, but stable "rules" which are identical both for all individuals in a group and across the different situations to which they are applied.

Habermas makes it explicit that this too is an idealization. Empirically, languages change over time. Individual linguistic habits and competence vary with dialects, social class, gender and age, and to some extent idiosyncratically. Furthermore, since people sometimes speak vaguely, figuratively or ironically, they may use the same words in different ways on different occasions. However, Habermas argues, idealization is necessary for a theoretical goal: the goal of "making clear the mechanism relevant to the coordinating power of speech acts" (Habermas, 1984b, p. 298). His argument goes like this: Only by assuming certain ideally stable rules in communication can we explain how individuals with different perspectives are able to understand each other in an infinite variety of situations. Therefore, to the extent that social actors aim at understanding each other, they will strive to follow the rules and expect others to do so as well. In this sense, stable rules are not only an idealization constructed by the social theorist in order to explain communication, but they are part of the social world itself.

To be sure, Habermas does not see the social world as a pre-established harmony commanded through and through by rules that everybody follows. On the contrary, he wants to account for a plurality of "validity claims" made

\footnotetext{
${ }^{3}$ This should be noted especially for the general thesis of reciprocal perspectives. It is a set of "idealizations" which establishes a "communicative common environment"; the general thesis is known to be (strictly speaking) false by the actors, who take it for granted only "until further notice" or "until counter-evidence appears" (Schutz, 1962a; Schutz, 1962b, p. 316). On the first two idealizations, see e.g. Schutz (1964b).
} 
by individuals with differing beliefs and preferences on different occasions. But what underlies such a plurality, he says, is a mutual understanding about the content of the respective claims. Without understanding what it is that others claim to be true or advisable, I cannot even begin to check if their claims are valid. And without others understanding me, I cannot contradict them or make claims of my own. "Understandability" lies beyond the plurality of "validity claims" since it is a precondition for making such claims at all (Habermas, 1984a, p.139). Debate and the communicative assertion of individual differences is only possible where there is a common ground, and that ground is provided, in Habermas's view, by the rules of a shared language.

Finally, given this fundamental role, Habermas presents language as paramount not only in communication, but in the "lifeworld" as a whole which provides "structures of linguistically generated intersubjectivity" (Habermas, 1987, p. 130).

Habermas presents this latter characterization of the "lifeworld" as a criticism of Schutz. As I have suggested, the difference between them lies not so much in the role of language, which both consider a central element of a social world. The crucial difference lies in their different views of linguistic patterns as (1) mere "types", i.e. as "taken for granted", but only "until further notice" (Schutz) - or (2) as "rules", i.e. as ideally invariant (Habermas).

But which view is the better one? We cannot decide by merely pointing to the fact that linguistic patterns do in fact vary over time and from individual to individual. Neither view ignores this fact, and both refer to "idealizations" of invariability on the part of the language users themselves. Schutz and Habermas differ, however, in the way they describe the dynamics of these idealizations in use (type vs. rule). We can find a way of assessing their descriptions if we read them as theoretical answers to the question asked above: on what basis is our precise and flexible linguistic communication possible? In the next section, I would like to examine whether a rule model of language (like that of Habermas) can offer us a convincing answer to this question. I will then return to the wider problem of how language and lifeworld are related.

\section{Assessing a rule model of linguistic communication}

In order to assess a rule model of language, we need a fair criterion for its performance. On the one hand, we should not put unreasonable demands on what Habermas calls the "coordinating power of speech acts". A phrase may be loaded with emotional nuances, connotations and personal experiences, but not all of this is actually communicated, and even less is communicated through language. All that language must do in Habermas's theory is provide 
a common ground on which plurality can unfold. On the other hand, the bar should not be too low either. What two or more individuals share using language in a concrete situation should have a minimum of specificity within that situation. Otherwise, we would fail to grasp the key role of language as a precise and flexible means of communication. In other words, we are looking for a robust core of meaning communicated through language.

Since Aristotle, a fruitful notion of such a meaning core has been handed down which Habermas (1998a) uses too: the proposition. ${ }^{4}$ A proposition is usually thought of as a representation which can be true or false and which would be either true or false given specific conditions, such as a certain state of affairs in the world. Many linguistic utterances (spoken or written) express a propositional meaning. ${ }^{5}$ With a declarative sentence, we can claim that certain truth conditions hold, whereas we can use interrogative sentences to inquire about the same conditions. With other types of utterances, we can promise that certain truth conditions will be fulfilled, we can order or ask others to fulfill them, etc. Propositions seem to be the gist of what we talk about, of what we actually say and not just 'mean'. They are specific enough to meet the lower bar for what is communicated, but they are not too specific to explode it. In most cases, the propositional content which an utterance expresses on a given occasion is easily identified and easily agreed upon. It is more or less obvious to the intuition of anyone who knows the language well enough. This would be consistent with the idea that language is a central element of a "lifeworld" as a world of shared familiarity.

We can now reconstruct the claim behind a rule model of linguistic communication. The claim is that our shared intuition about the propositional meaning core of an utterance in a specific situation can be explained with reference to "rules" in our shared language. These rules are assumed to be ideally stable across individuals and situations in the sense outlined above. In the following, I would like to assess the model by assuming hypothetically that such rules of language exist and checking whether their existence could in principle explain the possibility of precise and flexible linguistic communication as we know it. Following much of the literature in linguistics and the philosophy and sociology of language, our everyday intuitions about the propositional meaning of example expressions in various situations will be used as a yardstick. I will first ask to what extent ideally stable rules would sufficiently explain these intuitions (would they be precise enough?).

\footnotetext{
${ }^{4}$ Propositions also have a central role in Searle (2010, p. 27-30).

${ }^{5}$ Not every utterance seems to express a proposition ('Hello?' or 'Alas!' may not).
} 
I will then ask to what extent they would do so reliably (would they flexible enough?).

\section{Would rules sufficiently explain meaning?}

If the rules of language furnished everything we need to construe propositional meanings, we might expect the same sentence to have the same meaning in every situation of utterance. This is obviously not the case wherever indexical expressions occur. The pronoun 'I' does not always denote the same person regardless of who utters a sentence such as 'I feel sick'. But surely knowing who is said to feel sick in a given situation is part of knowing the propositional meaning of the utterance (i.e. knowing under which circumstances it would be true or false). The same problem arises with indexicals such as 'here', 'now' or 'this', and it can hardly be avoided. Although the rules need not sufficiently determine the meanings in all possible cases of language use, sentences without indexicals are rare at best; in fact, it is doubtful whether we could form sentences which truly dispense with indexicals at all (Lyons, 1977, ch. 15).

But perhaps the claim can be modified to accommodate indexicals. Indexicals are, as the word suggests, 'pointers', expressions which point at data beyond what is expressed. They indicate the direction in which a missing piece of information is to be sought. For instance, the word ' $\mathrm{I}$ ', as a rule, triggers a search for information and it seems to determine, again as a rule, that a person is referred to, and more specifically, the person uttering the sentence (Kaplan, 1989).

Whether or not this solution works for the word 'I' (see below for some doubts), it appears less than adequate in other cases. Take the word 'here'. We might venture the analogous rule that 'here' points to a place, and more specifically, to a place near the speaker (as opposed to 'there'). However, the places to which 'here' refers in different contexts are completely different both in kind and in relation to the speaker. 'Here' may be a smallish area beneath the speaker's feet ('Watch out, the ground is getting soft here!'), or a square surface a few meters in front of them ('The car was parked right here, wasn't it?'); 'here' may be the whole region excepting the zoological gardens ('There are no hyenas living here, right?'), a radius small enough to be reached by car ('Is there a gas station here?'), or the inside of the speaker's lower left canine tooth ('The pain is here.'). ${ }^{6}$ Evidently, any general rule to the effect that the word 'here' refers to 'a place near the speaker' falls far short, both in precision

\footnotetext{
${ }^{6}$ For similar examples see Hanks (1992) and Wittgenstein (2001, § 88).
} 
and in quality, of localizations which are intuitively clear and which concern, in some of these examples, the whole point of the utterance. Similar remarks could be made about other indexical and deictic expression such as 'that' (as in 'What the hell was that?'), 'it', 'then' or 'earlier', despite the fact that logicians have observed the problem and tried to solve it since antiquity (Bühler, 2011, p. 118). ${ }^{7}$ Apparently, the rules do not provide a "common ground" for our intuitive understanding of certain expressions. It seems more like the other way around: we read our understanding into the rules.

But a rule model might still contain this problem. It might concede that as far as indexicals are concerned, the rules do not sufficiently determine propositional meaning. But at least indexical expressions tell us exactly when and at which places in a sentence the rules fall short, thus delimiting sharply the problematic fields. In other words, indexicals could be read as public signals of their own insufficiency. The 'pointer' may not tell us clearly enough how the additional information is to be gathered, but at least it indicates that something is missing and triggers a search for information. It would be similar to a variable in an equation (as suggested by Lewis, 1970). And this would be part of the linguistic rules for an indexical.

Nevertheless, the problem reaches beyond indexical expressions. We can approach the full extent of the problem by seeing the poor specificity of indexicals as a case of vagueness or ambiguity: 'a place near the speaker' is too general, too wide a formula if compared to the various places the word 'here' may refer to. But indexicals are not the only linguistic structures suffering from this semantic anemia. Another example is the genitive case of many languages, which marks a noun as modifying another noun and which has various equivalents and companions (such as the noun compound or the possessive pronoun) in other languages. ${ }^{8}$ The genitive family may signify basically any sort of relation; compare 'my money', 'my dessert', 'my arm', 'my boss', 'my idea', 'my party', 'my turn'... The genitive has been described as semantically ambiguous, as referring to an abstract "relation R" or as "semantically non-specific" (Atlas, 2007, p. 227). Whatever the analysis of the rules involved, they certainly give us less than the propositional meaning expressed on concrete occasions.

\footnotetext{
${ }^{7}$ It might be argued that an indexical gains its full meaning only within the wider linguistic context of (a) the whole sentence, or of (b) the discourse in which the sentence occurs. In response, we could ( $a d$ a) give identical example sentences where the same indexical has different meanings in different contexts, and $(\mathrm{ad} b)$ point out that the above examples are clear in their meaning although presented as isolated sentences and would remain so if presented as the sole dialogue in a film skit or as speech bubbles in pictures.

${ }^{8}$ On noun compounds see Bühler $(2011$, p. $75,196,406)$.
} 
The same has been said for other types of words or constructions, including those which look at first sight like firm anchors for truth conditions, such as definite descriptions ('the king of France') and proper names (Recanati, 2010). Linguistic rules alone do not tell us who or what is referred to with these items. What is more, such examples of entire linguistic categories do not even begin to address the semantics of individual content words, of certain classes of nouns, verbs, adjectives or adverbs, or of more complex collocations which seriously underdetermine their propositional meanings (e.g. Bühler, 2011; Wittgenstein, 2001; Waismann, 1951; Atlas, 1989; Travis, 2008; Wilson and Sperber, 2012).

Most of this has been argued even for grammatically complete sentences. However, we do not always talk or write like this. Elliptical utterances and single words make up much of our daily language use. Perhaps we could treat such expressions as no more than lazy abbreviations of full sentences. ${ }^{9}$ But then the problem recurs in a different shape: how is it possible that we reconstruct those full sentences with such great ease in communication?

Phenomena of this kind have given rise to a variety of analyses as to what problem exactly linguistic rules run into where language users have no apparent problem at all. Some rules are too general and in need of specification, some rules branch out and need disambiguation, some are vague and lack any consistent standard of application. Whatever the analysis, the putative rules fall short of the concrete propositional meaning in ways which are not foreseen in the rules themselves. A giant additional apparatus of ever more fine-grained rules along with meta-rules for the application of lower-level rules could not (even if it were, despite an infinite rule regress, logically feasible) produce the wealth of actual meanings in context. This is because novel situations may arise which language users handle in novel ways. Our everyday intuitions of meaning are not grounded or generated by 'rules' alone.

I started out this discussion with indexicals. But the real problem lies with the insufficiency of rules in non-indexical expressions because the model cannot 'contain' this insufficiency. An indexical signals its own poverty and it may do so by virtue of a rule. But in many other linguistic devices, hypothetical rules fall short of the actual meaning in a concrete situation. And this very fact is hidden if we consider the rules only. The indexical signals, on a regular basis, a gap which needs to be filled or "saturated". But in other cases, our common understanding is based on a process of "free enrichment" (Recanati, 2002; Carston, 2002), an addition of meaning which is "free" in the

\footnotetext{
${ }_{9}$ This was argued by the early Jerrold Katz (Recanati, 1994).
} 
sense that it need not be triggered by a rule. This, however, implies that even those cases become problematic in which the rules would be sufficient. What I mean is this. In some cases, competent language use requires us to decide that the addition of meaning is required beyond what the rules prescribe. This decision is "free", i.e. it is not triggered by the rules themselves. But then the assessment that no such addition is required equally depends on a decision which is not covered by the rules alone. Even where the rules alone would give us all we need to construct the propositional meaning, our shared intuitive understanding that this is the case depends on an informed judgment made outside of the rule apparatus. Hence, the assumed rules are insufficient to explain our successful communication in any single case. ${ }^{10}$ They do not fully explain it even for a part or subdomain of language use.

\section{Would rules reliably explain meaning?}

I argued that hypothetical 'rules' of language fall short of propositional meanings. Assuming their existence would not sufficiently explain our linguistic intuitions. But perhaps rules would at least work reliably? Might not the rules of our language supply us with hard kernels or frames of shared meaning around which softer layers and textures are built as the situation requires? In this way, the rules would, without compromising their ideal stability, allow for a great deal of flexibility in whatever meaning is added.

We could begin to test the claim using, once again, the word 'here' (the fact that 'here' is an indexical is not important to the following discussion). If the rules for this word determine that it refer to 'a place near the speaker', we may concede that this information is too general and too meagre for a full proposition. But we could still claim that the word 'here' is reliably used to tell us at least this much. It would always refer, first, to a place, and, second, to a place near the speaker, whatever this means more specifically in context.

However, even this is not always conveyed by 'here'. Sometimes, the word is not used to refer to a place near the speaker but to a place near the audience. A doctor who, applying pressure to the area above her patient's liver, asks 'Does it hurt here?' is speaking from the patient's point of view. ${ }^{11}$ True, the

\footnotetext{
${ }^{10}$ The proponent of a rule model might want to make the 'hidden' problem public. For instance, she could mark, in the form of rules, all expressions which have displayed an insufficiency in the past or which might do so in certain cases. Or she could stipulate "hidden indexicals" (Recanati [2002] and Hall [2009] for a criticism of Jason Stanley's suggestions) in an attempt to turn 'free enrichment' into mere 'saturation'. But given the scale of the problem, she would in both cases restate the problem within the rule format itself: all, or most, language rules are insufficient - as a rule.

${ }^{11}$ John Lyons (1977, p. 677) calls this 'empathetic deixis'.
} 
patient's liver is near the doctor too, and she is even touching the spot in question. But even if she touched her own abdomen, her question 'Does it hurt here?' would be understood as referring to the corresponding area of her patient's body. In the case of a video conference, this area may be thousands of miles away from her. In the case of a health program on TV, she may refer to millions of livers scattered across the country. The localizations of 'here' with respect to the speaker will sometimes change within one utterance, for instance if somebody moves their finger across a map and states 'If we started out here and our current standpoint is here, we should be able to get out of the forest ... well, here'. When telling a story, someone may say 'He rode into the deserted town. What had happened here?' and refer, not to a place near himself or even near the audience, but to a place near a third party (besides, both place and party may be fictional).

Worse still, 'here' may not even refer to a place. It often refers to a point in time or to a topic, as in 'I must object here', 'Let's finish here for today', or (when listening to a $\mathrm{CD}$ together) 'The solo gets boring here, I think'. In still other cases, the word 'here' does not refer to anything at all but 'exemplifies' some of its own features (as any word can): it may be given as an example of a word with four letters, of an indexical expression (as seen above) - or even as an example of an example (as in the sentence you are reading right now). ${ }^{12}$

This variation in the meaning of 'here' represents phenomena which appear far more widely than this particular example. Some of the uses of 'here' are cases of indirect speech in a wide sense (for an early overview, see Vološinov, 1986). We often speak or write from the points of view of others. Sometimes we do so more directly by quoting, aping, echoing, or anticipating their words. Sometimes we do so more indirectly, as in descriptions given by ethnologists, historians or psychiatrists which change freely between the author's perspective and their subject's. This is to say nothing of jokes, theatrical performances, or lyrical texts. Indirect speech of one sort or another breaks even the seemingly reliable rule that the pronoun 'I' refer to the person uttering the sentence. Some other examples I have given point to the vast field of tropes such as metaphor ('here' referring to a point in time or a topic may be thought of as a metaphor), metonymy, hyperbole, oxymoron, irony, etc. It is clear that tropes will often produce radically different truth-conditions from what could be expected by looking only at the rules of semantics and

\footnotetext{
${ }^{12}$ Nelson Goodman (1968, p. 95) does not analyze the circumstances under which what he calls "exemplification" is used and how it is recognized, and his later work consistently leaves this question open. A rule model would be required to answer the question, somehow or other, in the rule format.
} 
grammar. These so-called 'rhetorical devices' structure large parts of our everyday language use.

Neither 'indirect speech' nor 'tropes' are restricted to particular words or domains. They can make even the slimmest rules unreliable for more or less any expression used in an indirect or figurative utterance. But comparable phenomena affect words and phrases even in their direct and literal application. The meaning of a word in context can sometimes be seen as the concrete application of an inherently vague concept. But meaning in context is often too far off from anything like the dictionary meaning, even though it is neither indirect nor figurative. In such cases, the underlying concepts do not seem to exhibit mere "vagueness", but an "open texture" (Waismann, 1951). On a similar note, cognitive scientists argue for the idea of "ad hoc categories" or "ad hoc concepts", which are constructed for the situation at hand by narrowing or widening in specific ways the concepts encoded by the language (Barsalou, 1983; Carston, 2002; Wilson and Carston, 2007; Vega Moreno, 2007).

All of the language uses outlined in this section produce different truthconditions from what could be expected on the basis of rules of language, however reliable these rules may seem if considered in abstract. If we tried simply to apply the rules found in dictionaries and grammar books to such utterances, we would not end up with the propositional contents that we - and other users of the language - understand the utterances actually to express. Our intuitive agreement on the core meaning is not accounted for by the power of rigorous rules in such cases. On the contrary, we seem to coordinate with intuitive ease in loosening, bending and breaking the rules. The rules are unreliable.

Could a rule model dispose of this problem by postulating additional rules? We should doubt it given the possibilities of flexibility and innovativeness which the research cited has consistently shown to exist. Some 'dead' metaphors, for example, might fit into a rule model since they are so standard that we could state extra rules for what they mean. But many metaphors are original and some are truly creative, as observed in the language performance even of small children (Bühler, 2011, p. 395). Again, this should not surprise us because language is used to say novel things in novel situations.

But perhaps the model can at least contain the problem? Some linguistic or paralinguistic signals indicate 'deviant' uses of one kind or another, e.g. quotation marks flagging indirect speech, or an ironical tone of voice. Sometimes, the 'deviant' uses are made explicit with the help of hedging expressions, introductions and comments. If an indexical signals its own insufficiency (as discussed above), then these devices might signal 
the unreliability of whatever falls into their domain. However, it is first of all not clear whether all of these cues themselves work according to reliable 'rules' ${ }^{13}$ But even if they do, they are not always present when the phenomena in question occur. We do not say 'metaphorically speaking' every time we use a metaphor. Most of the examples, given above, for different uses of the word 'here' work without any open signal of 'deviant' use. Apparently, we are so familiar with implicit deviations from linguistic rules that we do not need to signal them. Often we would even avoid signaling them, as in certain forms of irony, linguistic play of flirtation. Moreover, the phenomena of "open texture" concepts and "ad hoc" meaning construction occur in direct, literal, straightforward uses of language as well. It does not seem useful to call such uses 'deviant' to start with. As with the other cases, they pose a problem for a rule model, but not for our everyday understanding of language which that model is supposed to explain.

If the rule model cannot 'contain' the unreliability of rules, the problem reaches the same proportions as that of their insufficiency. The reasons are the same. If the decision to 'deviate' from a (hypothetical) rule apparatus is not itself triggered by a rule, then neither is the decision not to deviate, i.e. to simply follow the rules. Even if there were only a few spots of 'hidden' unreliability, the fact that these spots are not themselves signaled on a reliable basis would be enough to demonstrate that never and nowhere do linguistic rules provide a reliable ground for our intuitive grasp of propositional content. ${ }^{14}$ Rules then cannot even give us stable kernels or frames of shared meaning. Our use of language is too flexible for that, and it has no need for it either.

\section{Language and lifeworld}

The previous sections have shown that even if we assume the existence of stable 'rules' of language, we do not gain either a sufficient or a reliable ground for explaining our intuitions about the propositional meaning of utterances in context. Since the rules themselves do not signal where they are sufficient and reliable and where they are not, both problems affect the whole of language use. A rule model of language therefore does not work even for 'regular' or 'normal' cases, or for a part or sub-domain of language use. A rule model

\footnotetext{
${ }^{13}$ John Gumperz discusses a broad range of what he calls "contextualization cues" (Gumperz, 1992), but importantly, he does not present these as strictly rule-governed, but as dynamic and context-sensitive.

${ }^{14}$ To put it differently: if we aim to explain our linguistic coordination, any supposed priority of "normal" rule-following over what Habermas would call "parasitic" uses of language collapses because the rules of language themselves are unable to draw this distinction.
} 
fails to answer the question: on what basis our precise and flexible linguistic communication is possible?

This assessment does not necessarily cast doubt on the important role of language for communication and for a shared lifeworld more generally. It does, however, require a different view of language and linguistic communication. On the level of theory, the idealizations behind a rule model become useless. The model fails to meet the theoretical goal for the sake of which, in Habermas's case, the idealization of stable 'rules' of language was explicitly constructed in the first place. But if this is the case, the reason for attributing similar idealizations to the language users themselves also disappears. We do not follow ideally stable 'rules' in our linguistic production and comprehension, and we do not expect others to do so. We do tend to follow linguistic patterns and expect others to do so. But we are able and quite ready to deviate from the patterns, to modify or ignore them in actual use. In other words, we are oriented towards the patterns of our language only "until further notice", as Schutz would put it. To the extent that in doing so, we employ a kind of idealization (in the sense outlined above), it is best described as a dynamics of typicality. Linguistic patterns are types after all, as Schutz had claimed.

This implies a more complex relation between language and lifeworld. Habermas seems to suggest that the idealization of stable rules is a successful model for linguistic communication and should therefore be extended to the lifeworld. But if a rule model cannot explain communication even in the case of language, this strategy seems much less promising. The lifeworld cannot be thought of as an outgrowth of "linguistically generated" structures (Habermas, 1987, p. 130) from an already solid linguistic basis. Measured against the propositional meaning cores actually communicated by utterances, hypothetical rules of language are both insufficient and unreliable throughout. We do not base our shared understanding strictly on linguistic patterns and on them alone. Instead, we use our shared understanding in deciding where to follow the patterns and where to complement or suspend them. In a nutshell, Schutz already offered this argument when he criticized Husserl's view of the relation between language and lifeworld. It is not the use of language and other symbol systems which constitutes a "common environment", Schutz argued, but the other way around: it is a common environment which enables us to communicate using language (Schutz, 1966a, p. 38).

On the face of it, Habermas may be read as advocating a similar view. When we produce and understand utterances, we activate "background knowledge" (Habermas, 1998a, p. 240) which is part of our lifeworld as a "common ground of shared convictions" (Habermas, 1998a, p. 236). Returning 
to some of the examples given above, we could say that everyday knowledge about parking and filling up cars supplies more specific meanings for 'here' in some cases, and familiarity with doctor-patient interactions makes it clear that the patient's liver is meant by 'here' even when the doctor is pointing at herself. Nevertheless, we should reiterate: this "background knowledge" is not a supplement which builds on an autonomous foundation provided by rule-governed linguistic communication. Nor is it needed merely to fill gaps in such a foundation. Instead, this supplement is needed to make a rule model of communication work for any part of language in the first place.

Therefore, when Habermas writes that linguistic expressions are "embedded in the context of a lifeworld that is in turn linguistically constituted" (Habermas, 1998b, p. 334) or when he characterizes knowledge in terms of "grammatically regulated relations among the elements of a linguistically organized stock of knowledge" (Habermas, 1987, p.124), we should clarify his claims. If a rule model is to make sense at all, our lifeworld must follow ideally stable 'rules' of its own. More precisely: (1) The patterns of the lifeworld must have the same format as the hypothetical rules of language, and in this sense (if we think of language as a paradigmatic system of rules) we might say they are "linguistically organized". (2) Second, these rules must be distinct from the rules of language..$^{15}$ After all, lifeworld knowledge not only supplies utterances with full meanings (which is why rules of language alone are insufficient), but it is even able to override or modify the application of the linguistic rules (which is why they are unreliable). Would this extended rule model be plausible?

If they are to rescue the rule model, the 'rules' of the lifeworld have to carry a heavy burden. They must provide the context which gives an utterance its meaning. And they must do so not only in some cases, but even in cases where the bare rules of language would be sufficient, since only from the context can we judge where the 'rules' are sufficient and where they are not. Due to the flexibility of language, there are in principle no outer limits to what can be part of the context relevant to propositional meaning. Depending on the situation, the relevant context may contain linguistic elements as well as culture-specific knowledge; but it may also include information from the

\footnotetext{
${ }^{15}$ Searle makes similar claims (which should be clarified in the same way). The shared "skills and abilities" of what he calls our collective "Background" (Searle, 1983, p. 141) are a "reflection of", "sensitive to", "so to speak, functionally equivalent to" rules which are the reason for their existence, although they are not identical with them (Searle, 1995, p. 142). The "Background" is structured by "institutions" (for Searle, this includes linguistic rules), and institutions rely on a "formal linguistic mechanism" (Searle, 2010, p.7) as the "glue that holds society together" (Searle, 1995, p. 9).
} 
perception or memory of the participants in a communicative event, or information related to their current goals or emotional states (Sperber and Wilson, 1986, p.132). Due to the precision of language, there are also in principle no 'inner' limits to the degree of detail required of this contextual information. If we wish to save the rule model at the basic level of propositional meaning, all these possible fields of context must be "regulated", in advance, in every possible degree of detail by stable 'rules'. If any possibly relevant element were left out, the problem of insufficiency and unreliability would recur on the level of the lifeworld and again infect all of it, because the rules could not 'contain' the problem. The decision whether or not the rules of the lifeworld are sufficient and reliable would then depend, in all cases, on a decision made outside the extended rule apparatus.

By treating the lifeworld in this way as an indefinitely extensive and fine-grained apparatus of ideally stable rules, we could indeed save the rule model. We would give an answer to the question how precise and flexible linguistic communication is possible and how individuals can understand each other in ever new situations. However, this answer would deny any differences between the individual standpoints. It would describe the social world not only as a pre-established harmony, but as a world in which everybody has the exact same reaction to a given situation and therefore understands what others mean by what they say. In fact, intersubjective agreement would be so perfect that there would be little need for words at all. This consequence is absurd, and it would certainly exclude the plurality of "validity claims" which Habermas sought to ground with the help of his rule model of language.

Naturally, Habermas would not want to claim anything like this. He wants to combine a rule model with plurality and variation:

Certainly, grammatical rules guarantee an identity of meaning for linguistic expressions. But at the same time, they must leave room for individual nuances and innovative unpredictability in the use of these expressions, whose identity of meaning is only presumed (Habermas, 1992, p. 47).

Yet for the reasons given, such a mixed solution ${ }^{16}$ is not theoretically feasible. Linguistic rules are never reliable and therefore never "guarantee an identity of meaning" - unless we go all the way and accept the absurd rule

\footnotetext{
${ }^{16} \mathrm{~A}$ comparable mixed solution is offered by Searle, who wants to combine guarantees of social coordination we earn by using language "in the stereotypical appropriate way" (Searle, 1995, p.132) with "spontaneity, creativity, and originality" (Searle, 1995, p.141) in our social behavior.
} 
model of the entire lifeworld sketched above. But giving up an ideal identity of meaning means giving up the ideal stability of the 'rules', and with them the rule model as a whole.

What is the alternative? We could say that an identity of meaning is "only presumed" (to echo Habermas) in the following sense: social actors are oriented towards an ideal identity of meaning when using language and they tend to expect it from the linguistic performances of others; but at the same time, they are always open to producing and recognizing deviations from the ideal. But then we are talking about a quite different kind of idealization. It is more aptly expressed by Schutz's concept of "types" which are "taken for granted until further notice". ${ }^{17}$ Schutz's position, which describes both linguistic patterns and the patterns of the lifeworld in terms of types, is the more viable one.

\section{Conclusions: Phenomenology and social theory}

Is phenomenology outdated in social theory? I will first summarize the argument and conclusions of this paper and then sketch some perspectives for further research.

This paper focused on Jürgen Habermas's seminal criticism of Alfred Schutz. Their disagreement was reconstructed in terms of different roles they provide for idealization within a theory of linguistic communication. Given that our empirical language use differs across individuals and situations, the assumption of shared patterns already implies a degree of idealization. Schutz analyzes linguistic patterns in terms of "types". These are "taken for granted" by the social actors, who operate on a number of basic idealizations. But types are taken for granted "only until further notice", and in this sense they involve a dynamics of variation. Habermas explicitly rejects this dynamics, claiming that a stronger kind of idealization is needed to explain the possibility of communication. To the extent that only ideally stable "rules" make it possible for the social actors to communicate, Habermas argues, these rules are more than theoretical constructs; they are part of social reality itself. In his model, the 'rules' of language give us a solid ground of mutual understanding upon which a plurality of individual "validity claims" becomes possible.

\footnotetext{
${ }^{17}$ In later texts, Habermas might even have tacitly recanted his "radical" understanding of the lifeworld to which I referred to above. He now uses the formula "until further notice" ("bis auf weiteres") himself, but without referring to Schutz, and even the implicit reference is lost in English translations such as "at least provisionally" (Habermas, 2008, p. 36) or "only pro tempore" (Habermas, 2008, p. 41).
} 
A rule model was first assessed as far as patterns of language are concerned. Assuming hypothetically that these patterns are ideal 'rules', it was asked whether such rules could provide a ground for our intuitive understanding of what an utterance means. In order to choose a fair criterion, meaning was conceived as the propositional core content expressed by an utterance in context. This is a minimal requirement for grasping the flexibility and precision of language. A discussion of example utterances as well as a review of evidence and analyses from linguistics and the philosophy and sociology of language showed that the models fails even according to this minimal criterion. Putative rules of language give us less than what we understand to be the propositional content. The rules are insufficient. This is true not only in certain cases or domains of language use, but in every single instance. The reason is that the rules do not signal those cases where we actually know they need to be complemented. Hence, the rules do not explain our mutual understanding even in cases where applying the rules alone would be enough. Furthermore, our intuitive grasp of propositional meaning deviates from any putative rules of language. The rules are unreliable not only in certain cases or domains, but in every single instance. The reason is again that the rules do not signal those cases where are intuitive understanding deviates from them. Hence, the rules do not explain our mutual understanding even in cases where merely following the rules would yield the correct interpretation.

In conclusion, a rule model of language fails to answer the question: on what basis is our precise and flexible linguistic communication possible? It should be stressed that this failure is not only empirical, but first and foremost theoretical: The strong idealization of stable 'rules' of language does not meet the theoretical goal for which Habermas explicitly introduced it: to explain the possibility of communication.

Both Schutz and Habermas stress the central role that the patterns of a shared language play within a lifeworld in the sense of a shared and familiar social world. Habermas seems to go further when he claims that our language is the foundation for our lifeworld, and that a lifeworld is "linguistically constituted". Schutz criticized a similar position in the late Husserl, countering that linguistic communication is only possible at all within a wider framework of understanding. Given that linguistic rules alone are insufficient and unreliable and depend for communication on a mutual understanding which is able to complement or override them, Schutz is right.

It was considered whether Habermas's rule model would work if extended it to the "lifeworld". Rather than building on language as a sound foundation, this would mean adding more idealizations so that a rule model can work for 
language to start with. But while this strategy might be consistent in itself, it would lead to unacceptable conclusions. The reason is that there are in principle no boundaries to the context which can be relevant to understanding propositional meaning. In order to save the rule model of language, we would have to assume that the action and experience of every individual in a group follows shared and stable rules down to the last detail. We would thereby eliminate any differences between individuals, let alone a plurality of "validity claims". Since this conclusion is absurd, Habermas's idealizations fail to explain our communication even in an extended version applied to the lifeworld.

Instead, I suggested adopting the Schutzian view of both language and lifeworld in terms of types rather than rules. Like a rule model, this view accounts for the importance of shared, taken-for-granted patterns in linguistic communication and in the wider framework of a lifeworld. But unlike a rule model, the dynamics of types can equally account for the flexibility and precision of our linguistic communication. Schutz's position allows us to state that language is a central medium of typification within a lifeworld. But at the same time, it allows us to recognize that communication in that medium is not autonomous but involves an interplay with types outside language proper, e.g. with routines of action or patterns of attention and perception which are "socially derived", as Schutz would put it.

Insofar as the possibility of communication is essential to a social world, and insofar as language is the most flexible and precise means of communication, this would mean that phenomenology is not outdated in social theory, as Habermas and Searle ${ }^{18}$ have claimed. On the contrary, Schutz's approach seems to be the more advanced. Judging from the argument made in this paper, not only are sociologists right in seriously discussing phenomenological arguments, but social philosophers should do so as well. Various points made here were already made by Schutz in criticism of Husserl (and other phenomenologists). There is a rich history of phenomenological thought before rule models became dominant in various fields, and this history should be tapped in order to take the discussion forward.

Of course, the history of phenomenology does not offer ready and complete solutions to problems in social theory, and the discussion is not closed. In the context of this paper, the claim that we communicate using

${ }^{18}$ The parallels between Habermas and Searle noted in the course of the paper indicate that Habermas's criticism is similar to what John Searle may have had in mind when stating his (equally seminal) dismissal of Schutz's approach. 
mere types needs a more complex explanation than that given by a rule model. Yet phenomenology is not a thing of the past. Contemporary developments in phenomenology beyond Schutz may be instrumental on the way towards a fuller explanation. To conclude, I would only like to hint at one aspect important to the present discussion.

The dynamics of types can accommodate the flexibility and precision of language because types are taken for granted only "until further notice". But this latter qualification needs explaining. First of all, it must be more than a clause stating that we can deviate from a type if we run into a problem which forces us to do so. This is because the various phenomena exemplified above, while posing problems for a rule model, do not usually pose problems for language users. When people talk or write using metaphors, irony, ellipsis etc., they usually do so without hesitation and without first considering a more regular expression. Likewise, when people understand the meaning of such utterances, they usually do so directly and automatically, without first constructing a more regular interpretation and then dismissing it. Both the production and the interpretation of utterances actively and easily transcend typical patterns. Therefore, in addition to a tendency to follow types (to "take them for granted"), we should assume a tendency to transcend the types we take for granted. Such "spontaneity" can also be seen in fields of experience and action outside language use proper, and a phenomenological framework is suited to reflect both tendencies (Straßheim, 2016a; 2016b). The crucial point for a collaboration between phenomenology, sociology and social philosophy is that an active tendency to transcend types not only operates on the level of the individual but is a constitutive element of social phenomena. In our everyday language, we spontaneously supplement, modify or ignore shared typical patterns, and what is vital: we do so together. A theory aiming to capture the possibility of communication cannot, on pain of failure, idealize away from this fact.

\section{References}

ATLAS, Jay D. Philosophy without ambiguity: a logico-linguistic essay. Oxford: Clarendon Press, 1989.

ATLAS, Jay D. Meanings, propositions, context, and semantical underdeterminacy. In: Gerhard Preyer; Georg Peter (orgs.). Context sensitivity and semantic minimalism: essays on semantics and pragmatics. Oxford: Oxford University Press, 2007. p. 217-239.

BARSALOU, Lawrence W. Ad hoc categories. Memory \& Cognition, v. 11, n. 3, p. $211-227,1983<10.3758 /$ BF03196968>. 
BERGER, Peter L.; LUCKMANN, Thomas. The social construction of reality: a treatise in the sociology of knowledge. Garden City: Anchor Books, 1966.

BÜHLER, Karl. Theory of language: the representational function of language. Amsterdam/ Philadelphia: John Benjamins, 2011 [1934].

CARSTON, Robyn. Thoughts and utterances: the pragmatics of explicit communication. Oxford: Blackwell, 2002.

GARFINKEL, Harold. Studies in ethnomethodology. Englewood Cliffs: PrenticeHall, 1967.

GOFFMAN, Erving. Frame analysis: an essay on the organization of experience. London: Harper and Row, 1974.

GOODMAN, Nelson. Languages of art: an approach to a theory of symbols. Indianapolis: Bobbs-Merrill, 1968.

GUMPERZ, John J. Contextualizing and understanding. In: Alessandro Duranti; Charles Goodwin (orgs.). Rethinking context. Language as an interactive phenomenon. Cambridge: Cambridge University Press, 1992. p. 229-252.

HABERMAS, Jürgen. Wahrheitstheorien. In: Jürgen Habermas. Vorstudien und Ergänzungen zur Theorie des kommunikativen Handelns. Frankfurt am Main: Suhrkamp, 1984a [1972]. p. 127-183.

HABERMAS, Jürgen. The theory of communicative action. v. 1. Reason and the rationalization of society. Boston: Beacon Press, 1984b [1981].

HABERMAS, Jürgen. The theory of communicative action. v. 2. Lifeworld and System: a critique of functionalist reason. Boston: Beacon Press, 1987 [1981].

HABERMAS, Jürgen. On the logic of the social sciences. Cambridge: MIT Press, 1988 [1967].

HABERMAS, Jürgen. Themes in postmetaphysical thinking. In: Jürgen Habermas. Postmetaphysical thinking. Cambridge: MIT Press, 1992 [1988]. p. 2-53.

HABERMAS, Jürgen. Actions, speech acts, linguistically mediated interactions, and the lifeworld. In: Jürgen Habermas. On the pragmatics of communication. Cambridge: MIT Press, 1998a [1988]. p. 215-255.

HABERMAS, Jürgen. Some further clarifications of the concept of communicative rationality. In: Jürgen Habermas. On the pragmatics of communication. Cambridge: MIT Press, 1998b [1996]. p. 307-342.

HABERMAS, Jürgen. Communicative action and the detranscendentalized 'use of reason'. In: Jürgen Habermas. Between naturalism and religion: philosophical essays. Cambridge: Polity Press, 2008 [2001]. p. 24-76.

HALL, Alison. Subsentential utterances, ellipsis, and pragmatic enrichment. Pragmatics \& Cognition, v. 17, n. 2, p. 222-250, $2009<10.1075 /$ pc.17.2.02hal $>$.

HANKS, William F. The indexical ground of deictic reference. In: Alessandro Duranti; Charles Goodwin (orgs.). Rethinking context: language as an interactive phenomenon. Cambridge: Cambridge University Press, 1992. p. 43-76.

KAPLAN, David. Demonstratives. In: Joseph Almog; John Perry; Howard Werrstein (orgs.). Themes from Kaplan. Oxford: Oxford University Press, 1989. p. 481-563. 
LEWIS, David K. General Semantics. Synthese, v. 22, p. 18-67, $1970<10.1007 /$ BF00413598>.

LYONS, John. Semantics. v. 2. Cambridge: Cambridge University Press, 1977.

RECANATI, François. Contextualism and anti-contextualism in the philosophy of language. In: Savas L. Tsohatzidis (org.). Foundations of speech act theory: philosophical and linguistic perspectives. London: Routledge, 1994. p. 156-166.

RECANATI, François. Unarticulated constituents. Linguistics and Philosophy, v. 25, n. 3, p. 299-345, $2002<10.1023 / \mathrm{A}: 101526793>$.

RECANATI, François. Truth-conditional pragmatics. Oxford: Oxford University Press, 2010.

SCHUTZ, Alfred. Common-sense and scientific interpretation of human action. In: Alfred Schutz. Collected papers I: The problem of social reality. The Hague: Martinus Nijhoff, 1962a [1953]. p.3-47.

SCHUTZ, Alfred. Symbol, reality, and society. In: Alfred Schutz. Collected papers I: The problem of social reality. The Hague: Martinus Nijhoff, 1962b [1955]. p. 287-356.

SCHUTZ, Alfred. Making music together: a study in social relationship. In: Alfred Schutz. Collected papers II: Studies in social theory. The Hague: Martinus Nijhoff, 1964a [1951]. p. 159-178.

SCHUTZ, Alfred. Teiresias, or our knowledge of future events. In: Alfred Schutz. Collected papers II: Studies in social theory. The Hague: Martinus Nijhoff, 1964b [1959]. p. 277-293.

SCHUTZ, Alfred. Edmund Husserl's Ideas. v. 2. In: Alfred Schutz. Collected papers III: Studies in phenomenological philosophy. The Hague: Martinus Nijhoff, 1966a [1953]. p. 15-39.

SCHUTZ, Alfred. Type and eidos in Husserl's late philosophy. In: Alfred Schutz. Collected papers III: Studies in phenomenological philosophy. The Hague: Martinus Nijhoff, 1966b [1953]. p.92- 115.

SCHUTZ, Alfred; LUCKMANN, Thomas. The structures of the life-world. v. 2. Evanston: Northwestern University Press, 1989.

SEARLE, John R. Intentionality. An essay in the philosophy of mind. Cambridge: Cambridge University Press, 1983.

SEARLE, John R. The construction of social reality. New York: Free Press, 1995.

SEARLE, John R. Social ontology: Some basic principles. Anthropological Theory, v. 6, n. 1, p. 12-29, $2006<10.1177 / 1463499606061731>$.

SEARLE, John R. Making the social world: the structure of human civilization. New York: Oxford University Press, 2010.

SPERBER, Dan; WILSON, Deirdre. Relevance: communication and cognition. Oxford: Blackwell, 1986.

STRAßHEIM, Jan. The problem of 'experiencing transcendence' in symbols, everyday language and other persons. Schutzian Research, v. 8, p. 75-101, 2016a <10.5840/ schutz201685>. 
STRAßHEIM, Jan. Type and spontaneity: Beyond Alfred Schutz's theory of the social world. Human Studies, v. 39, n. 4, p.493-512, 2016b <10.1007/s1074>.

TRAVIS, Charles. Occasion-sensitivity: selected essays: Oxford University Press, 2008.

VEGA MORENO, Rosa E. Creativity and convention: the pragmatics of everyday figurative speech. Amsterdam: John Benjamins, 2007.

VOLOŠINOV, Valentin N. Marxism and the philosophy of language. Cambridge: London: Harvard University Press, 1986 [1929].

WAISMANN, Friedrich. Verifiability. In: Antony Flew (org.). Logic and language: first series. Oxford: Blackwell, 1951 [1945]. p. 17-44.

WILSON, Deirdre; CARSTON, Robyn. A unitary approach to lexical pragmatics: relevance, inference and ad hoc concepts. In: Noel Burton-Roberts (org.). Pragmatics. Basingstoke: Palgrave, 2007. p. 230-259.

WILSON, Deirdre; SPERBER, Dan. Meaning and relevance. Cambridge: Cambridge University Press, 2012.

WITTGENSTEIN, Ludwig. Philosophical investigations. Oxford: Blackwell, 2001 [1953].

ZAHAVI, Dan; SATNE, Glenda. Varieties of shared intentionality: Tomasello and classical phenomenology. In: Jeffrey A. Bell; Andrew Cutrofello; Paul M. Livingston (orgs.). Beyond the continental-analytic divide. Pluralist philosophy in the twenty-first century. London: Routledge, 2016. p.305-325.

Received: 31 May 2017

Approved: 26 Sept. 2017

Correspondent author:

Jan Strassheim

Hirata Heights 203

Rokkakubashi 5-14-14

Kanagawa-ku, Yokohama-shi

Kanagawa, Japan 